\title{
Issues concerning legal support of international shipping
}

\author{
Olga Simonova* \\ Admiral Ushakov Maritime State University, 93, Lenin`s avenue, Novorossisk, 353918, Russia
}

\begin{abstract}
The article focuses on international shipping governed by regulatory sources of a dual nature. This circumstance is due to the fact that international shipping is regulated both by international legal sources, for example, conventions, international treaties and customs, and by domestic legislation and judicial practice of the countries participating in international transportation. The research findings have indicated that, unfortunately, in practice there are often cases when the norms of national or international law have loopholes. Thus, a number of provisions of the International Shipping Rules do not coincide with the Russian Charter of Water Transport. In addition, the concept of "bill of lading" is often used in international law and is absent in Russian legislation. Therefore, the author proposes to eliminate the existing loopholes causing either high costs or litigation by finalizing national and international legislation. In this regard, the author considers specific examples and makes appropriate proposals aimed to close the identified loopholes in international and national legislation in order to minimize the costs and losses of the parties to the international transport agreement, and to reduce the number of controversies. Such urgent problems as the problem of piracy and the problem of pollution of the seas and oceans by ships also arise in freight forwarding business. The author proposes to toughen measures of responsibility for maritime piracy and for pollution of the seas and oceans by ships at the legislative level.
\end{abstract}

\section{Introduction}

In the $21^{\text {st }}$ century, the number of sea and transport lines between countries has increased due to the fact that the processes of globalization in world trade and economy primarily affect maritime transport. The International Maritime Organization is confident that the future leadership in international transport lies with sea transport [1]. Undoubtedly, this circumstance leads to an increase in the tanker fleet and in the number of shipments, which, in turn, has an impact on world trade. In this regard, it is important to assess the current state of affairs in the field of legal support of maritime transport, and have a clear understanding of the national and international regulatory sources that regulate maritime transport. The assessment of the legal support of sea transportation indicates that certain public law issues arising in the field of sea transportation need to be addressed.

\section{General characteristics of research object}

The research object is the relations between the subjects of international law amid sea transportation process. Thus, conventions, bilateral agreements, and national legislation have become the subject of research. The possibilities of the legal potential of maritime legislation have been determined and the existing problems in the field of maritime transport have been considered, which has led to conflicts of interests between the parties. Due to this precise reason, the compliance of specific norms of domestic and international legislation has been analyzed in the event of a dispute. In particular, the study has examined the principles of UNIDROIT applied in the situations when the parties adhere different Rules (for example, Hamburg or Hague-Visby) when entering the contract.

In the course of the study, the systematic and normative methods as well as the method of comparative jurisprudence were used. Thus, the systemic method identified in the system of international law is the norms regulating maritime transport affairs. The normative method and the method of comparative jurisprudence helped to carry out a comparative analysis of the norms of international and national law.

The scientific novelty of the study lies in the fact that it makes specific proposals aimed to solve the issues arising in shipping, and gives recommendations for improving the maritime legislation, for example, related to freight return.

\section{Advantages and disadvantages of tramp and linear forms of shipping}

The high throughput of shipping routes, shipping volume (90\% of the world cargo turnover), a relatively low cost are the reasons why sea transport is the most demanded in the world. 
The increased efficiency of sea transportation will solve organizational and legal issues that cause disputes and disagreements between the parties.

Currently, tramp and linear forms of shipping are in demand. Tramp irregular shipping implies the development of such a transportation system in which ships are not assigned to certain routes, which makes this form more mobile [2]. In cases of large cargoes transportation, voyage charter is used in tramp shipping.

However, linear regular shipping, which implements shipping on a specific route and schedule, is the most popular today. When delivering large cargo, liner shipping uses a bill of lading, according to which the carrier does not have to provide the cargo owner with a certain cargo space.

There are certain risks associated with maritime shipping, therefore, it is necessary for the national and international legislation to consider various cases of liability of the parties to the contract to the fullest extent possible and to specify a compensation for lost profits.

\section{Issues of legal support of maritime shipping under charter and bill of lading and possible ways to resolve them}

The carrier's liability for a charter and a bill of lading is determined by different sources of law, specifically, for charter - by national law, for a bill of lading - by international law, whose norms are not dispositive in contrast to the charter but a mandatory one.

Consequently, there arise disputable situations in which the existing gaps in the law do not allow to fully determine the carrier's liability. For example, Article 796 of the Civil Code of the Russian Federation [3] specifies the carrier's liability for deterioration, damage, partial loss of cargo. However, the issues of lost profits and compensation for losses are considered by Article 169 of the Merchant Shipping Code of the Russian Federation [4]. In accordance with the provisions of the article, not only the freight but also the current value of the goods can be collected from the carrier.

The shipping contract, as a rule, is concluded between cargo owners and transport companies. As soon as the cargo is received on the ship, the captain becomes the carrier, who gives the bill of lading to the goods owner either personally or through agents. The bill of lading has the form of either a security paper or a kind of receipt. For example, in the event of damage to the cargo, international legislation, in particular the Hague and Hague-Visby rules, will be used to determine the carrier's liability [5].

Article 3 of the Hague Rules deals with the obligation of the carrier to ensure the goods safety, and subparagraph (b) of paragraph 5 of Article 4 of the Hague-Visby Rules specifies the reimbursement of the goods market value under the shipping contract. However, these sources do not specify the return of freight. Therefore, it will not be possible to return the freight. In this regard, it is advisable to close this loophole in international law.
The legislation stipulates cases in which the carrier is relieved of liability. For example, if the cargo was damaged due to the fault of the crew or if the cargo was damaged while saving a person's life.

The third common source used when establishing a shipping contract between countries is the Hamburg Rules valid from November 1992, which distinguish the concepts of the contractor and the party establishing the contract. The Hamburg Rules are used in the following cases: firstly, if the contract of carriage has been established in accordance with the Hamburg Rules, or with regards to the legislation based on the mentioned Rules; secondly, if the loading or unloading of the goods has been carried out in the port of the participating country; thirdly, if a bill of lading has been issued in the participating country.

Noteworthy are the UNIDROIT Principles applied if the parties use different Rules when establishing a shipping contract [6]. The example is when the cargo has been loaded at a port that adheres to the Hamburg Rules and unloaded at a port that uses the Hague or HagueVisby Rules. It should be born in mind that in the event of a conflict situation, the Arbitration Court will be guided by the legislation of the country considering the case [7].

Domestic regulation of maritime shipping in our country is implemented based on the Merchant Shipping Code. At the international level, the Russian Federation uses multilateral and bilateral agreements on merchant shipping (for example, on technical issues) that it has concluded with many countries.

Controversial issues arise due to the fact that cargo turnover with other countries is increasing. They are sometimes difficult to resolve in view of the existing loopholes in international maritime law concerning international shipping.

In recent years, oil prices have been constantly growing. This causes fuel costs increase, which affects the shipping cost. Three well-known container lines, specifically, Maersk Line, MSC and CMA CGM, have announced modifications to bunker surcharges (BAF surcharge) due to stricter sulfur requirements in marine fuel. BAF surcharge is approximately equal to USD 300500 per a container. Thus, OOO "TBI-Service" located in Novorossiysk, which often used the services of MSC, was forced to look for new agents due to large surcharges, and began to choose the lines of CMA CGM, Happag Lloyd. The new IMO requirements have somehow affected all market participants [8].

In addition, logistics companies deliberately create a shortage of empty containers, empty seats, and then ask for a surcharge to find empty containers and spaces on ships. Because of this, companies, for example, OOO "TBI-Service", inflate the final price for a client who has to look for a more profitable option for sending the goods.

Additional difficulties in international shipping [9], contradictions and loopholes in national and international legislation are created. For example, our legislation lacks the concept of "bill of lading", which is often used in international law. As well, there are 
discrepancies between the provisions of the International Shipping Rules and the Russian Charter of Water Transport [10].

In practice, additional legal difficulties arise in cases of cargo loading and unloading. In particular, international law stipulates specific cases, in the event of which the carrier can unload the goods at a port not specified in the contract. According to domestic legislation, this is unacceptable. In the case of a precedent, the responsibility including financial costs lies with the logistics company since the carrier relies on the provisions of international law.

In such situations, when establishing a contract between a logistics company and a carrier, it is advisable to negotiate the conditions in such a way that in case of disagreement during shipping or at the port of destination, the company arranging transportation is not responsible for the problems that arise after loading the cargo on the ship, and the captain of the ship is responsible for the cargo.

In order to reduce the number of controversies and court cases, and to minimize the costs and losses of the parties to the shipping contract, it is necessary to close the identified loopholes in international and domestic legislation.

\section{Issues of preventing pollution of marine environment by ships and legal support of maritime transport safety (piracy issue)}

The problem of environmental pollution and the problem of ensuring maritime transport safety influencing the merchant shipping development are urgent nowadays.

Thus, on August 7, 2021, according to Rosmorcherrechflot, while injecting oil from the terminal of the Caspian Pipeline Consortium from the Greek tanker Minerva Symphonies, there was a burst release of 100 tons of oil into the sea near Novorossiysk. According to the Space Research Institute of the Russian Academy of Sciences, the area of the oil spill was about 80 square kilometers. The damage it has done to the flora and fauna is difficult to assess.

1. The conventions aimed to protect the marine environment do not establish the limits of responsibility of states in cases of non-fulfillment of the necessary requirements and pollution of the seas and oceans by ships carrying various cargoes. This circumstance leads to the fact that national legislation, as a rule, also ignores these issues.

Considering the fact that the problem of environmental pollution is a global problem requiring immediate resolution, possibly before closing the loopholes in international and national legislation, it is necessary to authorize the International Maritime Organizations to conduct monitoring aimed to identify cases of pollution of seas and oceans and to determine measures to eliminate contamination. At the state level, environmental requirements for the carriers' activities should be tightened.
2. The provisions of the international maritime law specify strict administrative and legal measures that are applied to violators of the rules related to the exploitation of major hazard [11]. However, in domestic legislation, in particular, in Chapter 11 of the Code of Administrative Offenses of the Russian Federation, insignificant administrative fines are indicated for these violations. Accordingly, a person in a state of intoxication and operating a ship with a cargo of several hundred thousand tons of dangerous goods, or having thousands of passengers on board, may be fined from one thousand five hundred to two thousand rubles. To compare, the fine for the driver of a car or motorcycle for a similar offense is fifteen times larger and is accompanied by a mandatory deprivation of the right to drive vehicles for up to two years (Articles 11.9 and 12.8 of the Code of Administrative Offenses of the Russian Federation). In this regard, it seems reasonable and advisable to adopt the provisions of international maritime law.

When solving the piracy issues, it is necessary to specify punishment for piracy and regulate the legal escorting of the merchant ships by military vessels within the framework of international and national law. Currently, piracy is not considered a crime by the International Criminal Court.

In addition, it is necessary to tighten the control associated with ships inspection, including the one for the technical condition. This requires expanding the competence of the control authorities (for example, the port administration) and equipping them appropriately. It is advisable to adopt a law "On ensuring the safety of water and air transport in Russia from illegal seizure, robbery or drowning", which will also toughen the liability of foreign ships that have violated the law and security of Russia and resolve the issue of costs associated with the introduction of a security system.

\section{Conclusion}

The study has made the following conclusions.

The outbreak of COVID-19 has had a huge impact not only on people's lives and states' activities but also on the global economy.

The ability of transport companies to timely deliver food, medicine, essential goods for people and production across continents depends on the ability of states to do everything necessary to overcome the pandemic and its consequences.

Shipping companies have to constantly adapt to a rapidly changing situation by adjusting their strategies and development plans.

The response strategy in planning the company's activities is based on the development of the worst-case scenario associated with outbreaks of a pandemic. We have to expect and calculate new government measures aimed to limit the virus spread in countries being key in the supply chain.

The human factor also plays an important role. It must be considered and possible risks must be minimized. It is necessary to maximally calculate the 
possibility of critical passages when the crew is deprived of the opportunity to get on the ship due to the port blockage. On the other hand, sailors can be forced to stay on board beyond the established time limits.

In these circumstances, it is necessary to expeditiously resolve the problems impeding the activities of transport companies even in normal mode.

Tramp and linear shipping remain the most popular forms. The shipping activity is formalized by written documents being a charter, a bill of lading, an agreement.

International normative sources regulating legal relations in the field of maritime transport are conventions regulating the legal regime of maritime spaces, ensuring navigation safety, protecting marine environment, considering the issues of the carrier's liability.

At the same time, the norms of international law and national legislation do not always regulate emerging precedents in the same way, for example, when loading and unloading goods, or when determining the liability of a carrier, etc.

The national legislation sometimes lacks concepts used by international sources of law, for example, the concept of "bill of lading" is not used in Russian.

As a result, there arise controversies resolved in court. Thus, it is necessary to close the identified loopholes in international and national legislation.

The current global problems affecting regional and world development are as follows: legal support of maritime transport safety (the piracy issue) and the pollution of sea waters by ships.

Due to the fact that the norms of international law specify a stricter punishment for violators of norms exploiting sources of major hazard than domestic legislation (Code of Administrative Offenses of the Russian Federation), the provisions of international maritime law should be adopted.

To prevent pirate attacks on ships, it is necessary to consider measures of responsibility for piracy activities at the legislative level, to strengthen control over the inspection of ships, and at the national level it is important to tighten the responsibility of foreign vessels that have violated the law and security of Russia.

It also possible to solve the problem of pollution of seas and oceans by ships by establishing measures of responsibility for violators at the international and national levels. In addition, it is necessary to expand the rights of the International Maritime Organizations in matters of monitoring the practice of polluting sea space by ships carrying cargo, and determining measures aimed to eliminate pollution. Environmental requirements for carriers at the state level should become more stringent.

In the context of COVID-19, shipping companies and port facility operators have developed Temporary Recommendations to ensure the safety of water transport. They tighten the control of access to the ship by the watchkeeping service, and increase the access regime at terminals and berths.
As well, the Ministry of Transport of Russia developed recommendations ensuring the sanitary safety of passengers and crew on cruise ships, in passenger terminals, in sea and river ports, and obtained approval from Rospotrebnadzor.

The global threat of the coronavirus infection spread has led to the adoption of measures by the government of a number of countries to prevent the spread of infection, one of which was the borders closure. The problem of changing crews led to a decrease in cargo traffic [12].

Kitak Lim, the Secretary General of the International Maritime Organization, issued the need to support merchant shipping and protect the interests of sailors amid COVID - 19.

To overcome the pandemic, the delivery of vital goods such as medicines and food is also of great importance.

On March 26, 2020, a summit was held on the challenges of international trade in a pandemic. The G20 leaders expressed the need to ensure the flow of medical goods, agricultural products and other goods and services. In addition, it was noted that unnecessary interference with international transport and trade should be avoided.

Undoubtedly, in these conditions, domestic water transport cannot do without state support. The Russian Union of Industrialists and Entrepreneurs has proposed to include maritime and inland waterway transport in the list of the most affected industries and in 2021 to subsidize shipping companies that are deprived of the ability to carry passengers for 5.2 billion rubles, to provide companies with interest-free loans for paying salaries and half-year holidays on loans and leasing without interest capitalization, etc. A proposal is being developed to introduce a moratorium on increasing port dues in seaports in 2021.

As practice has shown, to fully satisfy shipping needs, the maritime administration must function effectively. Unfortunately, at present, there is an unsatisfactory work of the public sector in solving emerging problems.

The work improvement will be facilitated by the coordinated work of a clear vertical government in the field of maritime transport and the corresponding infrastructure of various states. It is also necessary to expand the powers of state bodies related to ensuring port control and security in merchant shipping.

In Russia, the construction and development of modern infrastructure of seaports is of great importance [13]. And for this, it is necessary not only to ensure an uninterrupted procedure for the receipt of tax payments to local budgets but also to specify the possibility of private financing within the framework of public-private partnerships.

The targeted use of port dues will ensure the safety of navigation, order in seaports, and the mobile operation of port infrastructure.

In the context of the current crisis of maritime shipping caused by a pandemic, it is important to develop a modern logistic approach, a unified concept of organization, management and control over the activities 
of maritime transport based on the legal norms of international and national legislation [14].

Reaching a consensus on the issues under consideration will solve the global problems of our time.

\section{References}

1. A.L. Boran-Keshishyan, S.I. Kondratiev, A.N. Tomilin, Marine intellectual technologies, 1(43), 2, 149-156 (2019)

2. Trump shipping. Retrieved from: //wiki.wargamng.net

3. Civil Code of the Russian Federation (part two) dated 26.01.1996 N 14-FZ (revised from 09.03.2021). Retrieved from: SPS ConsultantPlus "

4. Code of Merchant Shipping of the Russian Federation dated 04/30/1999 N 81-FZ (as amended on 06/08/2020). Retrieved from: "SPS ConsultantPlus"

5. International shipping. Russia International Chamber of Commerce. The world business organization. Retrieved from: http://www.iccwbo.ru/blog/2016/mezhdunarodnyemorskie-perevozki

6. Principles of International Commercial Contracts. Retrieved from: studme.org> pravo> printsipy_mezhdunarodnyh_kom
7. N.A. Butakova, Rotterdam Rules: Analysis and Application Prospects, Civil Law, 3, 43-46 (2013)

8. About bunker allowances. Retrieved from: // https://seanews.ru/2018/09/25/ru-ro-bunkernyenadbavki/

9. E. Koroleva, S. Sokolov, I. Makashina, E. Filatova, Digital sea container terminal-an element of digitalization of container transport systems, E3S Web of Conferences, 203, 05004 (2020)

10. Code of Inland Water Transport of the Russian Federation" dated 07.03.2001 N 24-FZ (as amended on 08.06.2020) (as amended and supplemented, entered into force from 14.06.2020). Retrieved from: SPS ConsultantPlus.

11. V.V. Zaslonov, A.A. Golovina, Marine intellectual technologies, 2(52), 2, 132-139 (2021)

12. A.I. Epikhin, E.V. Hekert, M.A. Modina, Marine intellectual technologies, 2(52), 2, 38-46 (2021)

13. S.N. Zaikova, A.V. Titov, Transport of Russian Federation, 5(78), 50-53 (2018)

14. S.K. Abrahamyan, K.V. Golubkina, Marine intellectual technologies, 1(43), 2, 82-85 (2019) 